\title{
New Views on Course Ideology and Politics of Higher Education Curriculum in Post-epidemic Era
}

\author{
Jie Zhang ${ }^{1,2, *}$, Xiaojuan Zhang ${ }^{1}$, Xiaojuan $\mathrm{Wei}^{2}$, Wenqi Wang ${ }^{3}$, Yue $\mathrm{Ma}^{1}$ \\ ${ }^{1}$ College of Science, Xijing University, Xi'an 710123, China \\ ${ }^{2}$ Shanghai Institute of Technology, Shanghai 201418, China \\ ${ }^{3}$ Xihua University, Chengdu 610039, China \\ *Corresponding author. Email: zhangjiezdy@163.com
}

\begin{abstract}
In view of the urgent need to further promote the course ideology and politics in the curriculum of higher education in the post-epidemic era, combining the themes of 'China Vaccine', 'China support', 'China speed', 'China determination' and 'China Spirit' with the teaching of professional courses, the following four aspects are taken into account: adjusting physical and mental health, deepening the cultivation of patriotism, returning to the edification of Chinese classical culture, and participating in social practical training. This paper puts forward the ideological education mode and strategy of strengthening the social responsibility and patriotic feelings of college students, and puts forward the approaches and methods to guide college students to establish correct values and socialist outlook on life. Based on the hard process and successful experience of China, this paper points out the necessity and approach of training college students' ability to analyze and solve realistic problems innovatively.
\end{abstract}

Keywords: Epidemic situation, higher education curriculum, course ideology and politics, Corona Virus

Disease

\section{INTRODUCTION}

The sudden outbreak of the new crown disease has brought severe challenges to China and all over the world, but the face of the challenges has let people see a different China and all over the world[1]. Combining the characteristics of the sociality of university admissions, the marketability of personnel training, and the guarantee of education quality, we should make good use of the living examples of the 'epidemic' between China and the world, and take typical cases such as China's determination, speed and great achievements in developing five vaccines at the same time as a breakthrough point, the shocking cases under the epidemic situation and in-depth thinking and understanding through the ideological and political course of professional teaching in colleges and universities[2,3]. To moisten things in a quiet way to firmly lead the correct values, outlook on life and world outlook.

Through psychological guidance and ideological guidance, students are taught and influenced by the advanced deeds that embody the advanced nature and superiority of socialism, and water and fertilize in the ideological realm, on the matter of ' Situation '[4], on the matter of 'yes', on the matter of 'world'[5], on the matter of 'show'. Through the post-epidemic era of ideological and political courses, while teaching professional knowledge, improve the sentiment and awareness of students.

\section{ADJUST MENTAL HEALTH AND GUIDE CORRECT VALUE ORIENTATION}

College students are transformed from high school students, the body is developing, the mind is not yet mature, values are forming, psychological guidance has become the focus of ideological and political curriculum during the epidemic. Students were given real-time lectures on big data and typical cases of the epidemic, through psychological counseling, psychological relief and psychological relief, improve students to build confidence to overcome the epidemic, and effectively enhance the body immunity, and through the coordination of body and mind, the better psychological perception and adjustment effect can be achieved.

In the process of psychological adjustment, relying on the Internet information platform to break through the limitation of time and space, we have adopted the method of combining online and offline to face up to the hot topics and major social topics in the epidemic situation, so as to dredge up dead spots and guide without leaving any room, remove mental confusion from your mind, carry forward the positive energy and the main melody, and enhance the ability of value discrimination of college students, thus causes the university student to form the rationality, the mature home country sentiment and the master consciousness. 
Teachers of ideological and political theory courses in colleges and universities should fully explore the contents of ideological and political education contained in the professional courses, grasp the particularity of the teaching guidance of ideological and political theory courses in colleges and universities, stress the value of educating people, and realize the ideological and political theory courses'.

\section{CULTIVATE PATRIOTISM AND PROMOTE EDUCATION OF IDEALS AND BELIEFS}

Contemporary college students are growing up in the era of rapid information circulation, high rhythm and high speed of science and technology development. Information and globalization are influencing college students thought, behavior and value orientation in an all-round and deep way. Ideal and faith is the core of training contemporary college students to become socialist successors and laborers. Therefore, we should combine the opportunity of fighting the epidemic organically and make good use of the characteristics of independence, selectivity, variability and difference of college students in the value orientation. Cultivate the ideological situation of college students deeply with the elements of patriotism and socialist superiority, combine the superiority of the our party's centralized and unified leadership, the superiority of socialism in concentrating its efforts on handling important matters, and the superiority of the support from all sides when one side is in difficulty, the superiority of the people's interests above all else, actively making use of micro-blogs, Wechat, mobile phone networks and so on, to convey to the hearts of college students in a lively, kind, simple and pleasant way, and to enter their minds in a timely and effective manner, and through the vivid, kind, simple way firmly rooted in the mind.

We should actively explore the innovative mode of the course ideology and politics in the curriculum, bring into play the role of students as the main body and their subjective initiative, and combine the themes of 'China Vaccine', 'China support', 'China speed', 'China determination', 'China Spirit' and other anti-epidemic themes[6], organic integration into the teaching process of professional courses. We should earnestly fulfill the duty of guiding and educating college students, and pay attention to taking ideological, theoretical, friendly and targeted anti-epidemic cases so as to imperceptibly guide students to strengthen their national consciousness and enhance their patriotic feelings, inspire the sense of national pride and national honor, guide College students to patriotic, strong national ambition, national selfconscious into the specific efforts to learn knowledge and skills.

Through the combination of knowledge and practice, the organic combination of professional course teaching and ideological education, students can learn professional knowledge, at the same time, feel the value of life and understand the original intention of higher education, while the sublimation of thought and the perception of soul, will further enhance the study of professional knowledge and exercise capacity determination and motivation.

\section{RETURN TO CULTURAL EDIFICATION AND CULTIVATE THE RESPONSIBILITY AND RESPONSIBILITY OF THE TIMES}

The sudden outbreak of the Corona Virus disease has brought severe challenges to China and the world, but the face of challenges has let people see a different China and the world. How to combine the long and arduous process of fighting against the epidemic with the ideological and political education running through the daily teaching of colleges and universities, we need to find the opportunity and the joint point.

In the face of the continuous development of the epidemic situation and the reality of fighting against the epidemic situation, they are good at edifying the cultural attainments of college students with traditional culture, curing the problems of idleness, laissez-faire, self-interest, weak human relationship and weak faith.

By analyzing the anti-epidemic cases at home and abroad and the present situation of the protests, the education of life culture should be emphasized to guide the college students to think about the meaning and value of life and enhance their sense of social responsibility. Through watching and observing award-giving activities such as 'touching China' and 'national hero', the education of moral culture will be highlighted, and college students will be guided to feel the moral strength from all the people who are fighting in the front line of the epidemic, such as medical staff, so as to enhance their sense of social responsibility.

Through the objective reality of the successes and failures of the fight against the epidemic at home and abroad, the education of dialectical thinking should be given prominence, and college students should be guided to see the advantages of the socialist system from the mechanism of joint prevention, joint control and coordinated national prevention and control, improve the cognitive level of knowledge and behavior, clarify personal ideal and belief orientation, enhance the 'four self-confidence'.

By infiltrating ideological and political education through daily management and taking advantage of the opportunity of submitting safety and health information, students are required to strictly abide by the regulations governing the prevention and control of the epidemic, obey arrangements for not going back to school without permission, and consciously maintain public order, refuse to 'conceal report, late report, do not report' and other acts to enhance the sense of social responsibility, integrity and the concept of the rule of law. 


\section{PARTICIPATE IN PRACTICAL TRAINING TO ENHANCE THE CONSCIOUSNESS OF SERVING THE PEOPLE}

College students are the hope of the nation, the future of the motherland and the very precious human resources. It is an important task of higher education to train college students to become successors and laborers of the socialist cause.

Training College students to become laborers is an important task of higher education. With the help of the characteristics and requirements of the epidemic era, we should unify the ideals, beliefs and life values of university students into the purpose of serving the people wholeheartedly, and guide them to learn from the grassroots masses, to form a style of study that is diligent in study, good in thought and practical in study, to form the habit of combining theory with practice.

Through social practice and training, learning by doing, drawing knowledge and wisdom from the People's vivid practice, broadening their horizons and accumulating experience, so that college students can see their own shortcomings in the process of serving the people, to understand the true connotation of 'all talents and virtues', and to achieve the goal of increasing practical talents and enhancing self-confidence in value. Through the role exchange, self-management, supervision and inspection and other ways, so that the sense of responsibility gradually grow, experience and learn to assume social responsibilities and obligations. Manage yourself and others, out of the campus, deep into society, in practice to understand the society, deepen the understanding of book knowledge, so as to establish a sense of responsibility and sense of mission.

\section{CULTIVATE THE INNOVATIVE ABILITY TO FACE, ANALYZE AND SOLVE PROBLEMS}

\subsection{The Need for Innovation}

It is also an important task of higher education to cultivate the ability of university students to solve problems face-toface. Considering the impact of the new crown epidemic on the fate of mankind all over the world, universities should increase publicity of China's attitude, determination and ability in facing problems, encourage people to approach problems from different perspectives, to think about them, and to use different strategies and innovative approaches to solve problems. We should make full use of the learning and life experience of college students, create familiar life situations for them, stimulate their interest in exploration, create conditions for the diversification of problem-solving strategies, and present various expressions for students, teachers should give recognition, and actively guide and cooperate with students, so that each student in a different angle, depth and breadth have a successful experience. The liberal education is a very important and critical task in higher education, and the Corona Virus Disease provides a very good time for college students, we should face this disaster, but at the same time, we should make good use of this opportunity to promote the university students to face the problem, analyze the problem, solve the problem of innovative ability to grow quickly.

\subsection{Key Approaches to Innovation}

\subsubsection{Integration of science and technology with national conditions}

We should combine science and technology with the overall development of countries in the world to fight against the epidemic, and promote the attribution, purpose and service of science and technology development. In scientific research, we should also solve the fundamental problems of 'what kind of science and technology to study, how to do it, and for whom to do it'.

\subsubsection{Domestic versus foreign}

Looking at development from the perspective of history, we will enhance China's self-confidence in the fight against the epidemic, clarify its responsibility in the future, and strengthen its mission. By means of vertical comparison, students are helped to combine the knowledge points in books with the concrete problems in practice, and to deepen their understanding of the preciseness of scientific research, the arduous course and the goal of serving social progress, in order to better have the ability to face the problem, clear future efforts to break through the direction of travel.

\subsubsection{Fusion of science and spirit}

Inspired by the professionalism of the scientists who fought the epidemic and its far-reaching impact on human society, students are encouraged to pursue scientific careers. Combined with the fearless spirit of Chen Wei's team during the development of vaccines in China, China's innovative model of developing vaccines using five technical routes, namely, inactivated vaccines, recombinant protein vaccines, adenovirus vector vaccines, attenuated influenza vector vaccines and nucleic acid vaccines, arouses the interest in exploring professional knowledge, students can draw strength and faith from these scientists who are fighting the epidemic. 


\subsubsection{Unification of problem and model}

In the context of the world's fight against the epidemic, combining the legendary stories of the 'Vulcan Mountain' and the 'Raytheon Mountain', it guides students to experiment, communicate, reflect, evaluate, and improve as they continue to ask questions, explore, and solve problems, it refines the practical difficulties and problems into life model, cultural model, value model and technical model[7], and makes the teaching activities of professional courses more lively through the process of ideological and political education, let students form strategic thinking in the process of problem-solving, and gradually acquire the ability to find, analyze and solve problems.

\section{CONCLUSION}

Faced with the ravages of the new epidemic situation, university teachers should fully explore the contents of ideological and political education in the post-epidemic era contained in the professional courses, and grasp the particularity of the teaching guidance of ideological and political theory courses in universities, strengthen the health care, psychological relief and psychological relief, and continue to improve the psychological maturity of college students. In a good mood, we should strengthen the education of patriotism and socialist sense of superiority, promote the physical and psychological maturity of college students, eliminate the psychological confusion in thinking, and constantly enhance the sense of cultural identity and sense of ownership of the Chinese nation, eliminate the psychological confusion in their minds, and constantly strengthen the sense of cultural identity and sense of ownership of the Chinese nation.

\section{ACKNOWLEDGMENT}

This work was supported by the project of Innovation Ability of Colleges and Universities (2019B-059).

\section{REFERENCES}

[1] Lee mi-ru, Lee Ch 'iu-ling, Hou chi-min,Teaching practice and thinking of network live broadcast during new crown epidemic[J], Journal of Langfang Teachers College (Natural Science Edition). 2020, 20(04): 116118. (In Chinese)

[2] Zhang Yiming, How long until the disease is gone

[D], China economic times, 2021, 01, 06. (In Chinese)

[3] It's hard to beat the virus without a Chinese vaccine [D], Global Times, 2020, 12, 25. (In Chinese)

[4] Zhao Yan, Wang Jinmei, Tian Yuchen, On the teaching mode of ideological and Political Education of online courses for postgraduates under the new situation[J], Journal of Shenyang Institute of Engineering (Social Sciences Edition). 2021, 17(01): 130-133+138. (In Chinese)

[5] Nie Yingping, Fu Anzhou, The value aim and basic compliance of curriculum ideology and politics from the perspective of meaningful world 2020-12-31. https://kns.cnki.net/kcms/detail/detail.aspx?dbcode . (In Chinese)

[6] Wu Xiaoli, Ideological and political reform and innovation of history curriculum in colleges and universities-Taking ideological and political construction of "The Rise of Modern China" curriculum as an example [J], Education in Heilongjiang (theory and practice). 2021, (01): 35-37. (In Chinese)

[7] Sun Qiuye, Huang Yujia, Gao Jiawen, The project of ideological and political construction of Engineering Courses: taking the course of electric power system analysis as an example [J], Proceedings of the CSEE. DOI:10.13334/.j0258-8013.pcsee.201356. (In Chinese) 